\title{
Nationality-Based Criminalisation of South-South Migration: the Experience of Venezuelan Forced Migrants in Peru
}

\author{
Luisa Feline Freier $^{1}$ (D) - Leda M. Pérez ${ }^{1}$
}

Accepted: 9 December 2020 / Published online: 14 January 2021

(C) The Author(s), under exclusive licence to Springer Nature B.V. part of Springer Nature 2021

\begin{abstract}
This article examines how Venezuelan forced migrants in Peru experience xenophobic discrimination, which has become increasingly linked to their criminalisation as thieves and murderers. Based on 12 months of qualitative fieldwork, including 72 in-depth interviews, five focus groups, and a survey (N116) in five Peruvian cities, we explore how Venezuelans experience, and make sense of, discrimination and criminalisation in everyday life. First, we discuss how criminalisation compares to general xenophobic discrimination, and other types of discrimination experiences. Second, we juxtapose the prevalence of xenophobic discrimination and criminalisation experiences across the five cities of our study, and between public spaces and the workspace. We then move to the qualitative discussion of the criminalisation experience in these different spaces. Fourth, we discuss how Venezuelan migrants perceive this criminalising discrimination as linked to their villanisation in the media and political discourses. Finally, we discuss our findings and make suggestion for further research. The paper contributes to the literature on migrant criminalisation by exploring how criminalisation processes play out in the context of large-scale intraregional forced displacement in the global South.
\end{abstract}

Keywords Criminalisation $\cdot$ Securitisation $\cdot$ South-South migration $\cdot$ Venezuela $\cdot$ Peru

"Why are people from your country such thieves?" and I told him [the neighbour] "But, why is that my fault? I am not to blame for that. Now, look, come and see" [...] I had taken a screenshot and said to him "look, this man is Peruvian, he killed his neighbour,

Luisa Feline Freier

Lf.freierd@up.edu.pe

Leda M. Pérez

L.perez@up.edu.pe

1 Universidad del Pácifico, Lima 11, Peru 
quartered her body, killed her children, cooked her, and, because he didn't like her taste, threw the remains to the dogs. Are you to blame for this?" [...] You are not to blame for this. One cannot be blamed for this. This is just crazy!

\section{Introduction}

The abovementioned vignette cites 42-year-old Rafael from Barinas, Venezuela, in January 2020. In response to the xenophobic and criminalising remark made by his Peruvian neighbour, Rafael reversed the roles to showcase the absurdity of blaming all Peruvians for the gruesome murder committed by one Peruvian man. The interaction exemplifies the social criminalisation that many Venezuelan immigrants experience in their everyday lives in Peru.

Despite the increasing social and political significance of xenophobia, understood here as the "fear of difference embodied in persons or groups" (Berezin 2006: 273), against Venezuelan immigrants in Peru, and Latin America more broadly, this issue has been seldom explored in academic scholarship. The relevant literature tends to focus almost exclusively on migrant criminalisation in North America and Europe. This geographical lacuna exists despite SouthSouth migration accounting for about one-third of all international migration and for roughly half of all migratory movements departing from developing countries (Ratha and Shaw 2007; UN DESA 2012), and developing countries hosting 85\% of the world's refugees in 2019.

Venezuelan forced displacement across Latin America is an especially relevant case study for three reasons. First, Venezuelan emigration grew exponentially in the past five years and now represents the largest external displacement crisis in Latin America's recent history, and the second largest in the world (IOM 2020). As of mid-2020, about 1.8 million Venezuelans officially reside in Colombia, 830,000 in Peru, 455,000 in Chile, and 363,000 in Ecuador (UNHCR and OIM 2020). Second, while the initial policy responses to Venezuelan arrivals have been categorised as welcoming and generous in international comparison (Seele et al. 2019), more recently, the growing criminalisation of Venezuelan immigrants, and the securitisation of migration governance have been observed in countries such as Brazil, Chile, Ecuador, and Peru (Concha 2018; Freier and Parent 2019). Lastly, to date, little is known on how Venezuelan migrants experience, and make sense of, criminalising xenophobia.

Peru is the second largest receiving country of Venezuelan forced displacement in the region. Over the past years, the country has taken starkly different stands on the matter. Aron and Castillo Jara (2020) suggest that the country's policy response can be separated into two distinct phases. During the first one, under President Pedro Pablo Kuczynski (July 2016March 2018), the country took an active leadership position towards the reception and protection of Venezuelan citizens, facilitating their legal access to, and residence in, Peru. The second one, under President Martín Vizcarra (March 2018-November 2020), ${ }^{1}$ was characterised by closure and "securitisation" of immigration policies, which increasingly

\footnotetext{
${ }^{1}$ On November 9, the Peruvian congress impeached President Martín Vizcarra, applying a contested interpretation of the moral incapacity clause in the 1993 Constitution. This vacancy placed the President of the Congress of the Republic, Manuel Merino de Lama, as president of an illegitimate transitional government. Following seven days of uninterrupted, nation-wide protests, during which police brutality and repression left hundreds of people injured and missing, and claimed the lives of two university students, Merino de Lama announced that he was resigning to the presidency. On Monday, November 16, Congress elected Francisco Sagasti as the new President of Congress, and, therefore, head of the transitory government until the upcoming general elections on April 11, 2021.
} 
pushed Venezuelans into irregularity. This shift was likely motivated by increasingly negative public opinions and criminalising media discourses towards Venezuelan immigration (Amnesty International 2020).

In 2019, Peru's Ministry of Justice and Human Rights found that national media agencies frequently stressed the nationality of Venezuelan criminals, or suspects, even when this information was irrelevant to incidents being reported (MINJUSDH 2019). This kind of stigmatising reporting has been further aggravated by the utilisation of keywords or digital tagging (World Bank 2019). In this context, one especially violent crime was pivotal. In September 2019, the police found the quartered bodies of two young men, a Peruvian and a Venezuelan, in San Martin de Porres, a district in the capital city of Lima. Although it soon became clear that the violent crime was linked to international drug trafficking, "the quartering" came to symbolise the perceived link between Venezuelan immigration and an ostensible increase in crime for the media and in the public imagination.

In parallel, public attitudes towards Venezuelan migrants deteriorated, particularly in Lima, where around $80 \%$ of Venezuelan immigrants live, according to the 2017 Census (Gestión 2019). Already by the end of 2018, the perception of Venezuelans, as economic competitors for Peruvians, was high. In 2018, 72\% of respondents in Lima and Callao agreed with the statement that "the arrival of too many Venezuelans will harm the Peruvian economy," and $73 \%$ agreed that "Venezuelan are taking away jobs from many Peruvians" (IDEHPUCP and IOP 2020). By the end of 2019, these percentages had risen to 77 and $76 \%$ respectively.

Importantly, the criminalisation of Venezuelans in public opinion rose much more significantly. While, by the end of $2018,55 \%$ of respondents agreed with the statement that "many Venezuelans are responsible for criminal activities in Peru," this percentage increased to $81 \%$ at the end of 2019 (ibid.). In 2018, only 39\% of respondents agreed that "the majority of Venezuelans are unreliable or dishonest people"; however, in 2019, this percentage escalated to $61 \%$. In addition, mistrust towards Venezuelans (agreement with the statement "I am very mistrustful of Venezuelans who arrive to Peru") rose from 40 to $68 \%$, and fear towards this population (agreement with the statement "I am afraid of Venezuelans who arrive to Peru") increased from 24 to $52 \%$ (ibid.).

The aforementioned change in public opinion has been accompanied not only by increasingly restrictive immigration policies, which have de facto impeded the regular immigration of Venezuelans to Peru since mid-2019, but also by xenophobic political discourses against them. These discourses first focused on economic arguments, but in parallel with public opinion, they soon shifted towards a perceived link between Venezuelan immigration and crime. One prominent example is the speech former President Vizcarra gave in June 2019, when he announced the implementation of a "humanitarian" visa, as a requirement for entry into the country, in addition to continuing with the deportation of the so-called bad elements of Venezuelan migration (Venezuelans who had lied to the authorities about their criminal records) (Freier and Parent 2019).

While a critical debate on these criminalisation processes in Peru, and the region more broadly, is emerging, scholars have not explored how Venezuelans experience these processes in their daily lives. Addressing this gap, this paper examines how Venezuelans experience, and make sense of, criminalisation in their interactions with Peruvians, and in how far they perceive them as linked to media and political discourses. First, we review the literature on legal and socio-political criminalisation processes, and their effects on migrants' livelihoods. Despite the relatively low number of studies on the criminalisation of South-South migration, we highlight key texts set in Latin America and elaborate on their contributions. After 
presenting our data and methods, we proceed to the results. Finally, we discuss our findings and close with some recommendations for future research.

\section{The Criminalisation of Migration: a Literature Review}

The criminalisation of migration encompasses both judicial and socio-political processes, which are complementary. Recent literature on the former has examined the convergence of the criminal justice and immigration enforcement systems, a concept now termed as "crimmigration" (Armenta 2017). This literature has focused on related processes in North America and Europe (Abrego et al. 2017; Barker 2012; Huysmans 2006; Melossi 2003; Menjívar and Kanstroom 2014; Parkin 2013). Studies have explored the different areas in which immigrants and minorities are being criminalised, including police practices (Armenta 2016; Douglas and Sáenz 2013), incarceration (Escobar 2016), detention and the law (Bourbeau 2019; Menjívar and Abrego 2012). Crimmigration also appears in contexts of enhanced emphasis on national security, aimed at countering terrorism (Romero and Zarrugh 2018), and militarising the US-Mexico border (Kil and Menjivar 2006).

The socio-political criminalisation process, defined as the discursive and social construction of the idea of the immigrant as a threat (Maneri 2011; Parkin 2013), is based on the "negative stereotyping and criminalising of migrants and refugees in the dominant public discourse, and other public policies and practices" (Atak and Simeon 2018; also see Bourbeau 2011). The term is linked to xenophobic discourses on "undesirable" elements of society, a category that often includes migrants - who are seen not only as foreigners but also as "the other" - as well as paupers, beggars or members of marginalised ethnic groups. These social groups tend to be depicted as potentially dangerous, or intrinsically predisposed to committing crimes (Anderson 2013; Melossi 2003; Parkin 2013; Sigona and Trehan 2011; Weber and Bowling 2008), by the media (Menjívar 2016), as well as in politicians' public discourses (Bourbeau 2011).

With a view to the drivers of criminalisation of immigrants and the securitisation of immigration, contexts related to adverse economic conditions, such as unemployment, stagnant growth (Atak and Simeon 2018), and rising rates of irregular migrants, when considered a threat to sovereignty, public welfare, and national security (de Giorgi 2010), have shown to intensify the criminalisation of migrants. Although there is evidence that increases in immigration are associated with an increase in the fear of crime (Nunziata 2015), there is little evidence for any real correlation between immigration, including irregular immigration, and crime, and some authors even find a negative correlation between the two phenomena (Fasani et al. 2019; Reid et al. 2005; Wortley 2009).

Nevertheless, discursive criminalisation processes have very real effects on the daily lives, socio-economic integration, and wellbeing of immigrants and refugees. Xenophobic narratives, and the criminalisation of immigration by the media, have both been linked to an increase in hostile attitudes among national audiences (van Klingeren et al. 2015), and, even, in xenophobic violence (Burnett 2017; Koopmans 1996). Negative public opinions on immigration may, in turn, lead to an increase in votes for anti-immigration parties (Boomgaarden and Vliegenthart 2007; Burscher et al. 2015), and a tangible shift towards restrictive immigration policies, which constitute legal crimmigration.

We identify two gaps in the literature. First, it lacks an explicit discussion on the basis of which identifiers migrants are being criminalised. The literature on the USA and Europe, but also on countries in the Global South, such as South Africa, has discussed the criminalisation 
of irregular migration status (Abrego et al. 2017; Alfaro-Velcamp and Shaw 2016; Martinez and Slack 2013; Menjívar and Kanstroom 2014). Recent studies also show the criminalisation of asylum seekers in the USA and Europe, as well as in Israel, Turkey, and Australia (Biehl 2015; Hodge 2015; Kienast 2020; Orr and Ajzenstadt 2020). The latter focus has to be understood in the context of Tumlin's argument (Tumlin 2004), according to whom after 9/11, counter-terrorism, criminal, and immigration policies merged and discrimination in the USA and Europe expanded to immigrants and nationals of Arab and South Asian descent, with Islam becoming a pivotal ethnic marker (Hammerstad 2014; Lentin 2011; Sivanandan 2007; Tufail and Poynting 2013).

Research has further established a link between the criminalisation of immigrants and the racialisation of physically distinctive minorities (Abrego et al. 2017; Armenta 2016, 2017; Armenta and Vega 2017; Provine and Doty 2011). Here, racialisation does not only refer to putative phonotypical or biological difference, but it can also instrumentalise, or construct, ethnic and cultural traits, such as language as the basis of differentiation. Some case studies are concerned with particular nationality groups, such as Mexicans in the USA (Martinez and Slack 2013), or Ugandan women in Turkey (Coşkun 2018). Others study migrants' "ethnicities" based on regional origins, such as "Latinos" in the USA (Menjívar and Kanstroom 2014), "Eastern Europeans" in the UK (Parmar 2019), or "Africans" in Israel (Orr and Ajzenstadt 2020). What is lacking are theoretical considerations on when criminalisation focuses on specific identifiers, such as legal status, race or ethnicity.

A second gap is the empirical focus on criminalisation of migration in the Global North. Aside from some in-depth case studies, such as South Africa (Alfaro-Velcamp and Shaw 2016; Landau 2012), there has been little academic inquiry on crimmigration within the Global South. More specifically, there is scant work on the criminalisation of migration in Latin America, which is partly due to the region's limited experience, until recently, with the reception of high numbers of immigrants and refugees. Most studies have focused on the criminalisation of transit migration, especially from Mexico to the USA, and, more recently, from Central America to the USA (Lowenkron and Piscitelli 2019; Ruiz and Álvarez Velasco 2019; Sánchez 2015).

A core characteristic of the studies set in Latin America is their critical approach, departing from decolonisation theory, feminism, and the rejection of neoliberalism. In this sense, authors distance themselves from realist approaches to the criminalisation and securitisation of migration. For example, Varela (2020) understands the Central American caravans as a social movement of migrants, via a feminist and anti-racist lens, and studies the hardships that these migrants endure in their transit towards the USA. Estévez (2018a, b) analyses migration and asylum policies in North America, through the concepts of "biopolitics" and "necropolitics", and understands the criminalisation and racialisation of immigrants as part of a series of lifedestroying policies.

From a more realist, or critical realist, perspective, Wagner (2010) provides a media analysis, and Freier (2012) a state ethnography of institutionalised racism and migrant criminalisation, exploring the case of the securitisation of migration in Ecuador in both cases. Dias (2014) analyses how the focus on human trafficking has led to a securitisation of Brazilian immigration policy, and Oliveira Moreira (2020) analyses the legality of attempts by the Brazilian government to criminalise irregular migration.

In the specific context of Venezuelan forced displacement across the region, Freier and Castillo Jara (2020) and Aron and Castillo Jara (2020) examine the shift in Peruvian migration governance, from openness to securitisation. Leon Rojas (2020) argues that various countries 
in the region have opted to control migration through border militarisation, assuming securitist policies. Other commentators have also observed the socio-political criminalisation of Venezuelans in Peru (Condori et al. 2020; Pecho Gonzáles 2020), and in the region (Pineda and Ávila 2019; Garcia 2020), including the criminalisation of return migration to Venezuela (Palma 2020). Bahar et al. (2020), on the other hand, look at migration and crime data from Colombia, Peru, and Chile and show that, for the most part, Venezuelan migrants commit substantially fewer crimes - and certainly fewer violent crimes - than the native born, relative to their share in the overall population. Yet the academic literature on this issue remains nascent. Importantly, we know virtually nothing about how Venezuelans experience the criminalisation of their nationality in their everyday lives.

\section{Data}

The research presented here is based on a multi-sited qualitative study conducted between 2018 and 2020 in five Peruvian cities: Arequipa, Cusco, Lima, Tacna, and Trujillo. These departments hold the majority of the Venezuelan population in the country: Arequipa (with 3\% of the total Venezuelan population in Peru), Cusco (0.7\%), Lima (83.8\%), Tacna (0.4\%), and La Libertad (3.9\%) (Gestión 2019). We collected both qualitative and quantitative data through 72 in-depth interviews, five focus groups, and a survey (N116), which we applied to 44 men and 72 women. Interviewees were at least 18 years old, had arrived in Peru after 2017, and worked at least once since their arrival. The survey collected descriptive data on migrants' socioeconomic characteristics, and the migration journey, whereas the in-depth interviews and focus groups inquired about their migration and integration experiences, as well as encounters with discriminatory acts and attitudes (see Annex, Table 5 and Table 6 for more detailed information). ${ }^{2}$

\section{Methods}

As noted in the data section, we employed three different instruments to collect and triangulate information on Venezuelan's migratory and integration experiences in Peru. Both men and women completed surveys (N116) prior to beginning the focus groups and interviews. The pre-programmed survey was implemented using tablets, and was filled out either by the participants themselves (focus group) or by the interviewer (in the case of interviews). The survey data was then processed using the STATA software.

For our in-depth interviews (N72), we recruited our first 15 interviewees in Lima through snowball sampling. Subsequently, as we began to organise our work in other cities, we employed the help of local contacts, either through NGOs or different multilateral organisations, such as the United Nations High Commissioner for Refugees (UNHCR) and the International Organisation for Migration (IOM), to contact potential interviewees. We followed a semi-structured interview guide, which allowed for the inductive inclusion of the interviewee's interests and concerns (see Annex Table 5). Interviews were recorded and lasted

\footnotetext{
${ }^{2}$ This research forms part of a larger study on the gendered experiences of Venezuelan immigrant women in Peru. For this reason, interviews were conducted exclusively with women, while focus groups were organised exclusively with men.
} 
between one and two hours. The five focus groups (N44) followed the same criteria, but were applied exclusively to male participants. Through snowballing and contacts provided by NGOs and multilateral organisations, we organised focus groups of eight to ten men in each of the five cities. These lasted approximately two hours and were moderated by at least two researchers. Each participant was given a turn to share his experiences before engaging in a group discussion.

All interviews and focus groups were recorded and transcribed. We used inductive coding for the systematisation and analysis of the data, and identified five main types of discrimination our interviewees experienced: (1) nationality-based xenophobia; (2) nationality-based criminalisation; (3) gender discrimination; and discrimination based on (4) age and (5) race. ${ }^{3}$ In most cases, participants experienced more than two of these types of discrimination. For the purposes of this article, we focus on nationality-based xenophobia and nationality-based criminalisation. The former refers to discrimination based on being a Venezuelan immigrant more generally, while the latter encompasses experiences where the migrant is seen as a potential criminal or accused of a crime, such as robbery or murder, based on his or her Venezuelan nationality. The research team conducted its own Spanish-English translations for all quotes included in this article.

\section{Results}

In this section, we present the socio-demographic description of the sample. We then discuss how experiences of criminalisation compare to general xenophobic and other types of discrimination experiences. In the next section, we juxtapose the prevalence of xenophobic discrimination and criminalisation experiences across the five cities of our study, and between public spaces and the workspace. We then move to a qualitative discussion of the criminalisation experiences. Finally, we discuss how Venezuelan migrants perceive this criminalising discrimination as linked to the villanisation of Venezuelan immigrants in the media and political discourses.

\section{Socio-demographic Description of Our Sample}

The demographic data collected in our survey reflects the socio-demographic characteristics described for Venezuelan immigrants in Peru in larger studies (INEI 2019; IOM 2020). The majority of the sample (78\%) arrived in Peru in 2018, and 12\% arrived in 2017. Our participants were young, with an average age of 37 years, and the majority was married (64\%). Participants had high levels of education, as $65 \%$ had at least some university education, while $15 \%$ had received a technical education. In Venezuela, participants had been employed in the sales, health, and education sectors. In Peru, however, they were mainly employed in the service and sales sector, mostly working with no formal contracts. The majority had some form of legal status: $62 \%$ had the special temporary permit, PTP, $18 \%$ were asylum seekers, $11 \%$ a permanent residence permit, and only $5 \%$ had no regular migration status.

\footnotetext{
"In this study, we understand "race" not as a biological category of human genetic variation, but as a sociocultural and cognitive construct (Brubaker et al. 2004).
} 


\section{Prevalence by Type of Discrimination}

The survey asked participants about their experiences with discrimination in Peru. The initial question was whether they had felt discriminated against based on their nationality (yes or no). The second question asked whether there were other motives based on which they had felt discriminated against (yes or no). The third question was open ended and asked what these motives were. Table 1 shows that nationality-based xenophobia was by far the dominant form of discrimination experienced by Venezuelan immigrants (71\%). This experience was gendered: while $61 \%$ of men had been discriminated against based on their nationality, this number increased to $77 \%$ for women. Discrimination based on gender was mentioned by $16 \%$ of women. Intriguingly, migratory status did not come up as a basis for discrimination, and, only in very few cases, interviewees brought up instances of racial discrimination. ${ }^{4}$

In the interviews and focus group data, we identified an even higher prevalence of nationality-based discrimination, than in the quantitative surveys ( $85 \mathrm{vs} .77 \%$ in the case of women, and 68 vs. $61 \%$ for men). ${ }^{5}$ Prevalence rates of xenophobic discrimination also varied according to participants' age. In the survey, we found that younger participants expressed that they had experienced situations of xenophobic discrimination more often than older participants $-78 \%$ of participants younger than 35 years old shared that they had experienced discrimination due to their nationality, compared to $63 \%$ of participants over 35 . We found no difference with a view to class, education, and legal status.

While participants did not explicitly identify criminalisation as a type of discrimination in the quantitative survey, the qualitative data reveals that, for many, criminalisation of their nationality was a main aspect of the nationality-based xenophobic discrimination they experienced: $33 \%$ of women and $24 \%$ of men shared experiences of criminalisation as Venezuelans. Table 2 presents the main types of discrimination identified in the semistructured interviews and focus groups by gender. Furthermore, most of the participants that identify experiences of criminalisation work in the service, sales, and health sectors. This may be connected to the fact that these occupations require direct contact with the local population. Prevalence rates of nationality-based criminalisation, however, are not determined by age, education level or legal status.

This section has shown that nationality-based discrimination, which is highly correlated with the criminalisation of their nationality, is the main form of discrimination that Venezuelan migrants residing in Peru experience. Prevalence rates for the former are shaped by participants' gender and age, while in the case of criminalisation, rates vary according to participants' gender and occupation, but not with regard to age. Importantly, legal status and racial selfidenitification did not significantly influence the criminalisation experience.

\footnotetext{
${ }^{4}$ Other forms of discrimination that where mentioned were discrimination based on higher education ( $3 \%$ of women and $5 \%$ of men), and discriminations based on age (4\% of women) and civil status.

${ }^{5}$ This disparity speaks to the strengths of qualitative methodologies in allowing for more open-ended responses, as opposed to quantitative methodologies, which tend to operate under clearly delineated question-response schemes. During the interviews and focus groups, participants discussed nationality-based forms of discrimination without explicitly identifying them as such, which suggests an under-reporting of such experiences in the surveys.
} 
Table 1 Type of discrimination experienced by gender (based on quantitative data)

\begin{tabular}{llll}
\hline & Nationality-based xenophobia & Discrimination by gender & Discrimination by race \\
\hline Women & $77 \%$ & $16 \%$ & $1 \%$ \\
Men & $61 \%$ & $2 \%$ & $5 \%$ \\
\hline
\end{tabular}

\section{Spaces of Xenophobic Discrimination and Criminalisation}

Regarding our study's geographical scope, we found a similar relationship between experiences of overall nationality-based xenophobic discrimination and criminalisation across the five cities. Both xenophobic discrimination and criminalisation were slightly more prominent in the capital city of Lima (experienced by $71 \%$ and $37 \%$ of our sample), and significantly higher in the coastal cities of Tacna (90\% and 40\%) and Trujillo (80\% and 39\%), compared to Arequipa (63\% and 31\%) and Cuzco (64\% and 33\%), two cities located in the Peruvian highlands (see Fig. 1).

In Lima, the higher concentration and visibility of the Venezuelan migrant population, and higher perceptions of insecurity and crime in general (INEI 2018a, b), can explain this difference. The data in Tacna and Trujillo was collected later, which might be indicative of an increase in criminalisation over time. As discussed above, public perceptions towards the Venezuelan population in Peru have deteriorated and become increasingly linked to criminalisation (IDEHPUCP and IOP 2020).

According to the interview data, about one-third of participants experienced general nationality-based discrimination in public spaces, which included interactions between Venezuelan migrants and Peruvian nationals in the streets, public transportation, and public and private services (see Table 3). These discriminatory acts range from "bad looks," verbal attacks, and exclusion from access to public and private services, for example taxi drivers who refuse to except Venezuelan clients, to physical assaults .

Xenophobic discrimination was more pronounced in the work place. Almost two-thirds of participants shared that they had been discriminated against based on their nationality at work, either during job interviews or when looking for a job, for example, when personally leaving CVs at establishments, as part of unsolicited applications. According to the quantitative survey, out of all the participants who were working, those employed in the service sector reported higher rates of nationality-based discrimination (80\%), compared to those employed in the education or health sectors (approximately 68\%).

In particular, participants frequently cited offences made by colleagues and superiors, suggesting that Venezuelans were "poor" and "replaceable", which translated in worse working conditions and lower salaries for Venezuelans compared to Peruvians in similar positions. Participants also shared situations of discrimination in which Peruvians refused to be assisted by "foreigners." The category "other spaces" includes interactions between Venezuelan migrants and Peruvian parents at schools; $18 \%$ of the participants with children

Table 2 Type of discrimination experienced by gender (based on qualitative data)

\begin{tabular}{lll}
\hline & Nationality-based xenophobia & Nationality-based criminalisation \\
\hline Women (interviews) & $85 \%$ & $33 \%$ \\
Men (focus groups) & $68 \%$ & $24 \%$ \\
\hline
\end{tabular}




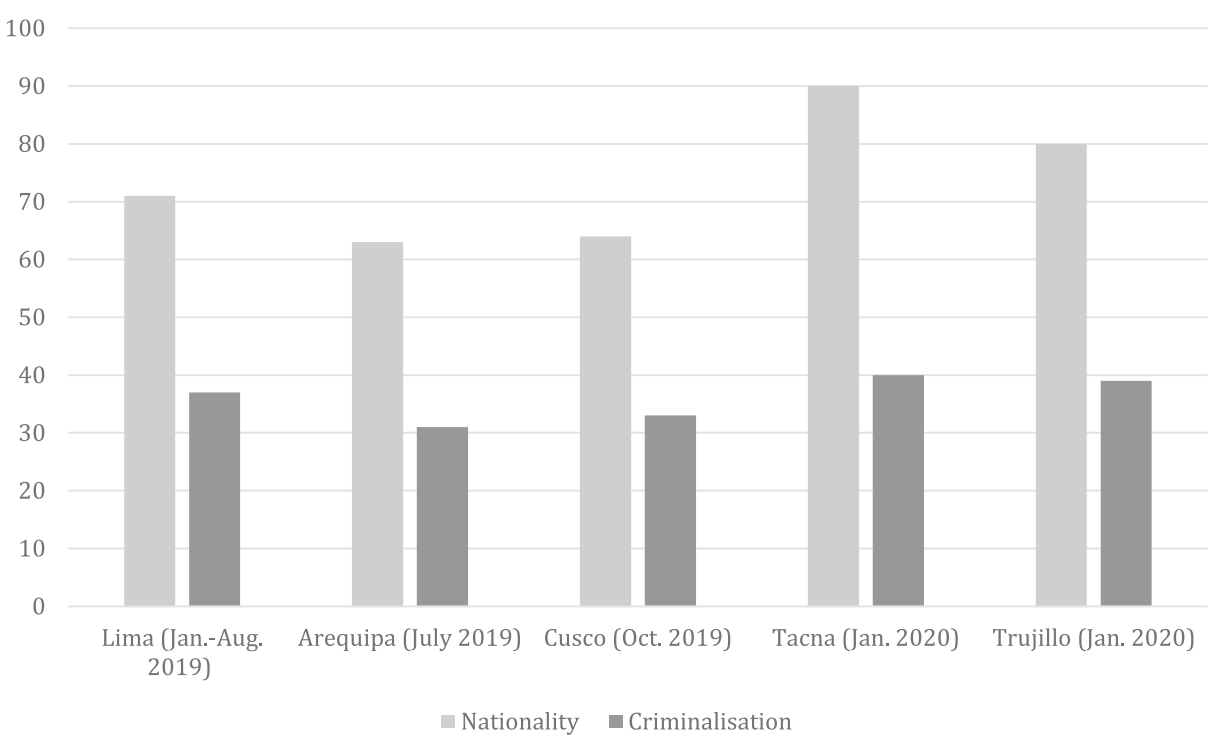

Fig. 1 Type of discrimination experienced by city (in \% based on qualitative data)

experienced their children being discriminated against by both peers and their teachers. Similarly, some parents reported feeling excluded by Peruvian parents.

In contrast to general xenophobic discrimination, criminalisation occurs more frequently in the public space, than in the workplace, and men and women face similar experiences of criminalisation in the public space (43\% versus $40 \%$ ) (see Table 4). However, in the workplace, women mentioned experiencing more situations of criminalisation than men $(43 \%$ versus 24\%). As mentioned above, participants who work in the service and sales sector are also more prone to experiences of criminalisation, irrespective of their level of education. In situations in which Venezuelans had secured a more "professional" position that was more closely aligned with their educational backgrounds, reports of criminalising discrimination were less prevalent.

\section{Criminalisation Experiences}

Criminalising offences in public spaces target Venezuelans as a group. Participants' testimonies cite Peruvians using slurs to accuse Venezuelans of being thieves or murderers. Having experienced a wide range of criminalising acts, Humberto, one of the participants in our focus group in Arequipa, expressed:

I have experienced extreme xenophobia here (...) I've been called a murderer, a thief, I've been spat in the face, everything has been done to me on buses... it is not even a

Table 3 Spaces of xenophobic discrimination (based on qualitative data)

\begin{tabular}{llll}
\hline & Workplace & Public space & Other \\
\hline Women (interviews) & $57 \%$ & $33 \%$ & $10 \%$ \\
Men (focus groups) & $60 \%$ & $31 \%$ & $9 \%$ \\
\hline
\end{tabular}


Table 4 Spaces of criminalisation (based on qualitative data)

\begin{tabular}{llll}
\hline & Workplace & Public space & Other \\
\hline Women (interviews) & $43 \%$ & $43 \%$ & $13 \%$ \\
Men (focus groups) & $24 \%$ & $40 \%$ & $36 \%$ \\
\hline
\end{tabular}

man of your size who comes to bother you, so that you can defend yourself, or hit him, no, above all, it is old people, children, teenagers who start saying those things to you, which is demoralising.

Similar to Humberto's case, one of the participants of the focus group in Cusco explained that he felt that Peruvians' fear of Venezuelans was reaching absurd levels. He recalled that one day, while he was selling apple pie on the street and spreading icing on the pie, a Peruvian bypasser screamed, "these Venezuelans want to kill us, take photos, look at this," implying that the icing was poisonous. Lilibeth (22, from Portuguesa) told us about hearing slurs directed towards her when taking public transportation in Arequipa, which combined the criminalisation of Venezuelan nationality with the hyper-sexualisation of Venezuelan women (see Pérez \& Ugarte, forthcoming):

"Now it's a question of "she is Venezuelan, she is a thief or she is a prostitute," an infinity of things,. Sometimes people get on a combi [small bus of public transport] and start yelling at me saying that I should get off because I'm a thief or prostitute.

Criminalisation in the workplace was frequently linked to Venezuelan immigrants personally being accused of theft because of their nationality. During an interview, Claudia (38, from Zulia), who was living in Cusco at the time, shared an anecdote with us about her time working at a laundry/dry cleaner establishment:

A lady wanted to pick up her jacket, but she hadn't brought the receipt and was giving me another name. I looked in my notebook, but found nothing. So [...] "ah, but you are" - I was here with my husband - "Ah, but you are Venezuelans, I hope nothing gets lost here." In other words, insinuating that, since we are Venezuelans, we were going to steal her clothes $[\ldots]$ You have to take a deep breath, swallow and ... and stay calm.

Similarly, Ana Lucía (33, from Tachira) told us about her experience working as a school janitor in Cusco. One day, a couple of teenage boys were studying in a room where she had been cleaning, and one of the boy's phones went missing. The next day she was called in by the assistant principal, who explained that the student had accused her of stealing his phone. Recalling the series of events, Ana Lucía stated:

They called the kid, I think [he] was 17 years old [...] he arrived looking embarrassed. So I said, "no, look... I need you to tell me why you think I was the one who took the phone, when you, yourself, saw everything, everything I did, well, all of my work." So, he said, "no, what happens is that, well, you are the cleaner and you are Venezuelan." [...] In other words, he discriminated against me on both counts, for my nationality and for my job.

In contrast to Claudia's case, Ana Lucía experienced being criminalised based on both her nationality and her occupation as a janitor. Teachers and caregivers in our cohort also described being criminalised by parents or employers, who catalogued them as violent and 
expressed fear that they might hurt their children, either in a school- or home-based setting. Relatedly, during our interview, Belinda (34, from Monagas) told us about the comments that some parents had made to the administrator of the school where she worked in Arequipa:

"How is it that the assistant is Venezuelan?" they told my boss. Parents fear that a Venezuelan is caring for their children since there are many Venezuelans on the street doing bad things... "What if she does something to my son, if she hits him or does something worse..."

Similar to Belinda's case, Deysi (29, from Aragua) told us about her experiences working as a waitress in Trujillo, where clients would call her a quarterer, in the context of the quartering of San Martin de Porres discussed above:

When I passed by their tables, [clients] would say "watch out, they'll quarter you" or "watch out, Venecos [pejorative term for Venezuelans] are murderers", comments like that

Finally, criminalisation is not only experienced by adults but also extended to schoolchildren, a phenomenon that often times acts as a barrier to their full integration. During our interview with Gocha (27, from Tachira) in Trujillo, she shared her children's experience at school:

The last school year was the worst for my 7 year-old boy and me. They discriminated against him so much at school [...] I'm going to start crying. Look, they told him they didn't want him [at school] because he was black and Venezuelan, that he was a criminal. As a mother, I felt the anguish, because [...] how am I going to explain to my son that he is not a criminal? You can't make a child pay for the things that someone else has done [...] My son went to the psychologist because they told him that he was a criminal. He did not want to live because they told him that he was a Venezuelan and a criminal, and that he should not exist. He himself said that.

Gocha's son's experience of being criminalised is based both on stigmatising conceptualisations of his nationality and his race by students at his school.

\section{Criminalisation in the Media, Political Discourses, and Law Enforcement}

Overall, participants' testimonies highlighted that that they see nationality-based criminalisation as closely connected to the media's generalised portrayal of the Venezuelan migrant population as criminals. This systematic bias has led the local media to predominantly cover cases of crimes perpetrated by Venezuelans (Pecho Gonzáles 2020). As Efrain (29, from Guarenas) explained:

The newspapers here are dedicated to propagating political propaganda that the Venezuelan is bad. That is all they show here. Why don't they show something good that the Venezuelan has done? Nothing. All that happens is "that the Venezuelan is stealing, the Venezuelan is doing this, that there is a Venezuelan" and even if you are not Venezuelan, they'll say "he [the criminal] spent time with three Venezuelans"... They want to destroy us.

In the focus group we conducted in Cusco, the group agreed that two crimes committed by Venezuelans, and their respective coverage, had been key in negatively influencing public opinion against Venezuelans: "the quartering" that took place in San Martin de Porres in 
September 2019, and the local murder of a businessman from Cusco at the hands of his Venezuelan employee in March 2019 (Correo 2019). Cesar (47 years old, from Tachira), who had arrived in Cusco two years earlier, explained how local perceptions of the Venezuelan population starkly changed after these events:

At the time I arrived, there were few Venezuelans. I mean, they loved us; seeing a Venezuelan here was rare, and most businessmen loved Venezuelans, and now they don't want them anymore... I recently had an experience, I was staying at another place in another neighbourhood, and the landlady threw me out because she told me: "You know that you are a descuartizador [a quarterer]"... ¿Descuartizador, me? Please! The landlady gave me two days to move, she didn't care that she threw me out the way she did... She gave me two days to vacate the room.

Adela (36, from Barinas), who was residing in Tacna at the time, also referred to "the quartering" of San Martín de Porres when pointing out the following:

A xenophobic campaign occurred because of what happened in Lima [referring to the quartering]. It was basically like... they insisted on doing this to cover up many other things that were happening in the country. Yes, what happened in Lima was very serious, but they showed it on the news for 15 days, morning, afternoon, and night. So, what I told some people was "look, people have also been quartered here and they show it only once and that's all." When I arrived, there were cases. I mentioned similar cases to them and the [they said] "oh, I did not know". Imagine, they did not know, but it happened. So, at that time, we were scared to even speak [revealing our Venezuelan accent] because people were very tense.

Focus group participants also agreed that the negative reporting and public opinion on Venezuelan immigration was increasingly reflected in political discourses. Romulo (35, from Monagas), who participated in the focus group in Cusco, felt that Venezuelans' "number one enemy is the media and not Peruvians." Angel and David, two other participants in our focus group in Cusco, also echoed this sentiment in the following dialogue:

Angel (35, from Carabobo): I read the news almost every day and something impressive happened to me the other day. It was the case that some Venezuelans, ah, Venezuelans would get [Peruvian] nationality. It wasn't a small report, it was large, almost the entire first page of the newspaper, and [then there was] a small minuscule square for a report on a rapist who had raped his daughter. And kept raping her...

David (38, from Mérida): But he was a Peruvian.

Angel: Yes, he was a Peruvian. But since it was not news on Venezuelans - because those impact you - and the rapist, that is, his daughter, in the news, so small, no photo, nothing, normal, like normal news.

David: But what sells are the Venezuelans...

Angel: What sells are the Venezuelans, in red and large.

David: Fortunately, they have made good money in the yellow press - at our cost. Angel: But it's not so much the politicians, it's more the media, because that sells. David: No, the politician too - because, what happens? The community sees, the community listens, and they begin to make noise, the noise reaches the politician, they pressure the politician, and the politician begins to do crazy things, there are several communications... 
Angel: Sure, but also because of public opinion and the media, they go hand in hand.

David: I do not remember exactly the province but there was a statement where Venezuelans are given until December 24 to leave... ${ }^{6}$

Similarly, participants in Trujillo's focus group agreed that mass media had a negative impact on their experiences in Peru-they felt that the media over-reported crimes committed by Venezuelans, instead of documenting the overall positive and negative impacts of Venezuelan immigration. Ana Lucía further shared with us the experience of the criminalisation of her husband in Cusco, which occurred, as she pointed out, irrespective of his skin colour:

At least in the case of my husband, of the two times that they have taken him into custody, he was beaten one day (police officer). Yes, Mr. Darwin, who is a man who lives with us, was also beaten. He is white, white, because my husband is dark, but he is white, white. They beat him, handcuffed him, walked him through the Plaza de Armas handcuffed. (...) and several of the officials told them "you have no rights in this country, your rights stayed in Venezuela." So, these are things that sometimes hurt.

\section{Discussion}

General nationality-based discrimination, or xenophobia, may be related to historical experiences or negative imagery associated with that nationality, ethnic national identity (Berezin 2006; Hjerm 1998), external threats and in-group instability or violence (Cashdan 2001). It may also derive from culture shocks, based on language and expressions, habits and forms of social interactions, and are often linked to physical appearance of "race" or "ethnicity" (Sáenz and Douglas 2015), which has been termed "culturally-based racism" in other South-South contexts (Tafira 2015). Nationalitybased criminalisation, on the other hand, specifically constructs the immigrant as a criminal threat. Based on 72 in-depth interviews, five focus groups, and a quantitative survey (N116) in five Peruvian cities, our study analysed the multifaceted ways in which Venezuelan immigrants in Peru experience, and understand, nationality-based criminalisation. Overall, our results show that Venezuelan immigrants' experiences with xenophobic discrimination are strongly linked to the criminalisation of their nationality. This finding stands in contrast to the existing literature that focuses on criminalisation based on irregular migration status, religion, and race or ethnicity.

At the same time, we put forward that these experiences are not monolithic, but rather shaped by migrants' various identity markers, such as gender, age, education level, and occupation, as well as mediated by particular environments. While self-reported discrimination based on race was extremely low among participants, this does not mean that race, ethnicity, and/or physiognomy were not present in interviewees' outlook. Participants found that Peruvians recognised them based on a quick assessment of their physiognomy, language, and social style. As Efrain (29, from Guarenas), one of the participants in the Lima focus group, explained:

\footnotetext{
${ }^{6}$ Here, David referred to a measure that was taken at the time the focus group was conducted by the district of Pichari in Cusco. The policy intended to "expel" the Venezuelan nationals residing in the district and gave them two months to leave. Despite being later revoked by the district, this measure shows the extent of the negative public perceptions of Venezuelans (Sputnik 2019).
} 
[The discrimination] is based on being Venezuelan, our physiognomy is different to that

of Peruvians, it is very different. And it's based on fear...

Importantly, some testimonies suggest that Venezuelans self-perceived as "racially superior" over Peruvians, usually in terms of being "better looking". Thus, nationality-based criminalisation was not experienced as linked to "racial inferiority", but rather to selfperceived "racial superiority". This suggests that criminalisation in South-South contexts ought to be studied from an intersectional perspective, taking into consideration local socio-racial hierarchies, where race tends to be interlinked with gender, education, and class, and socioracial differences operate as a relational continuum, or mosaic (Freier et al. 2021).

In addition to the prevalence rates, xenophobic discrimination and nationality-based criminalisation experiences also have to be assessed within the particular spaces in which they take place. We found that these processes vary when experienced in public spaces or the workplace. In public spaces, they occur in the form of slurs that express generalised negative perceptions of the Venezuelan migrant population as a group. Participants highlighted experiences of verbal abuses while taking public transportation, in the street, and when trying to access public services, including healthcare and education. In the workplace, xenophobic discrimination and criminalisation are more personalised and occur when participants interact with clients or colleagues, or superiors. Many participants recalled being accused of being thieves while working.

We also find some important differences in the ways in which men and women experience nationality-based discrimination and criminalisation. For one, the testimonies of the men who participated in the focus group revealed that their experiences with criminalisation are limited to the workplace and the public sphere. By contrast, the women interviewed indicated experiencing criminalising marginalisation through their children, who have also tended to be accused of thievery at school. Likewise, while men are thought to be thieves or murderers, women may be perceived to be thieves, husband-snatchers, and/or prostitutes.

Finally, participants in our study understood these experiences as being caused by an increase in negative and xenophobic portrayals of Venezuelan immigrants in the media, particularly linking them to criminal activities, and in political discourses and actions. Venezuelan migrants perceived this change in media reporting, and resulting effect on public opinion, to have intensified after the San Martín de Porres "quartering" in Lima in September 2019. This highly mediatised event had very real effects on the daily lives, socio-economic integration, and wellbeing of Venezuelan migrants, as Rafael shared in the introductory vignette.

\section{Conclusion}

This study makes an important contribution to the literature by studying the experiences of nationality-based criminalisation of Venezuelan forced migrants in Peru. Our study suggests that, in the context of South-South migration, where culturally end ethnically similar populations move towards destination countries with largely informal labour markets and limited state and welfare services, legal immigrant status and racial or cultural markers, such as religion and race/ethnicity, matter less, than nationality, in comparison to findings on SouthNorth migration. Further studies should deepen our understanding of the criminalisation of South-South migration in the context of local social-racial hierarchies.

With a view to the specific case of Peru, additional research should also analyse how nationalitybased criminalisation poses as a significant barrier for Venezuelan migrants' socio-economic 
integration, and negatively affects their wellbeing, as indexed by the high prevalence rates of common mental health disorders among this population (Carroll et al. 2020), and include fullfledged gendered analyses. Another theme for exploration is migrants' use of coping mechanisms in response to their experiences with xenophobic discrimination and nationality-based criminalisation. Participants in our study often cited strategies for avoiding being seen, and, in some cases, remaining silent in order to not be differentiated, as well as reverse discrimination against Peruvians, and segregation processes within the Venezuelan migrant population.

For a large number of South American countries, including Peru, Venezuelan forced migration presents a first real test to their progressive and rights-based immigration discourses and legislation of the twenty-first century (Acosta and Freier 2015; Cantor et al. 2015). It seems that with growing numbers of immigrants, and rising concerns about insecurity and crime in public opinion and the media, Latin American countries are increasingly engaging in the same kind of migrant criminalisation, and the securitisation of migration governance, they long criticised in Europe and North America (ibid.). In the context of the COVID-19-related sanitary and economic crises, such tendencies are intensifying across the region, and have even led to the proposal of securitised immigration bills, often directly targeting Venezuelan immigrants in various countries (Freier and Luzes 2021). Gaining a better understanding of the socio-political criminalisation processes of Venezuelan immigrants in the region thus also remains key in empirical terms.

Acknowledgements The authors wish to thank Soledad Castillo Jara, Nicola Espinosa, Andrea Kvietok and Marta Luzes for their excellent research assistance.

\section{Annex}

Table 5 In-depth interviews

\begin{tabular}{|c|c|}
\hline Domains & Questions \\
\hline $\begin{array}{l}\text { Migration } \\
\text { experience }\end{array}$ & $\begin{array}{l}\text { - What does migration mean to you? } \\
\text { - Why did you decide to migrate? } \\
\text { - How was the trip? Who did you come with? } \\
\text { - Why did you decide to come to Peru (Lima, Arequipa, Trujillo)? } \\
\text { friends, parents, etc.) } \\
\text { - What has been your experience in the process of obtaining / regularizing your stay in this } \\
\text { country? }\end{array}$ \\
\hline $\begin{array}{l}\text { Work } \\
\quad \text { experiences }\end{array}$ & $\begin{array}{l}\text { - What jobs have you had since you arrived? } \\
\text { - About every job she's ever had ask about: }\end{array}$ \\
\hline Discrimination & $\begin{array}{l}\text { - Since you arrived to Peru, have you ever felt discriminated against? What was the reason } \\
\text { (nationality, skin colour, gender)? }\end{array}$ \\
\hline $\begin{array}{l}\text { Plans for the } \\
\text { future }\end{array}$ & $\begin{array}{l}\text { - What are your next personal and work plans? } \\
\text { - What are your hopes? } \\
\text { - How did you get the job? } \\
\text { - What were the activities you had to do at work? } \\
\text { - Wow much do you get paid? benefits? contract? } \\
\text { - What was your work schedule? What days did you work? } \\
\text { - Where are the employers from? } \\
\text { - Why did you leave that job? } \\
\text { - In general, has your work experience in Venezuela been recognized/appreciated here? } \\
\text { - Do you have or have you had any obstacles to get a job because of your immigration status } \\
\text { or lack of any procedure / registration? } \\
\text { - Do you think it is easier for a man or a woman to get a job? Why? }\end{array}$ \\
\hline
\end{tabular}


Table 6 Focus group

\begin{tabular}{ll}
\hline Domains & Questions \\
\hline Migration experience & - How long have you been in Peru? \\
& - Which form of transport did you take to come? \\
- How was the experience of the migration journey? & - What does migration mean to you? \\
- How many of you are working at the present? & - In which field? \\
- Howk experiences & - How is the work environment with your employers and colleagues? \\
& - If it is necessary: How many of you are not working at the time? \\
& - Hhy not? \\
& - How long have you have been without work? \\
& - Do you think it is easier for a man or a woman to get a job? Why?
\end{tabular}

\section{References}

Abrego, L., Coleman, M., Martínez, D. E., Menjívar, C., \& Slack, J. (2017). Making immigrants into criminals: legal processes of criminalisation in the post-IIRIRA era. Journal on Migration and Human Security, 5(3), $694-715$.

Acosta, D., \& Freier, L. F. (2015). Turning the immigration policy paradox upside down? Populist liberalism and discursive gaps in South America. International Migration Review, 49(3), 659-696.

Alfaro-Velcamp, T., \& Shaw, M. (2016). 'Please GO HOME and BUILD Africa': criminalising immigrants in South Africa. Journal of Southern African Studies, 42(5), 983-998.

Amnesty International (2020) 'Perú: Buscando refugio: Perú da la espalda a quienes huyen de Venezuela' Amnistía Internacional Perú, 4 February 2020, https://www.amnesty.org/es/documents/amr46/1675/2020/es/

Anderson, B. (2013). Us and them? The dangerous politics of immigration control. Oxford: Oxford University Press.

Armenta, A. (2017). Racializing Crimmigration: Structural racism, colorblindness, and the institutional production of immigrant criminality. Sociology of Race and Ethnicity, 3(1), 82-95. https://doi.org/10.1177/ 2332649216648714.

Armenta, A. (2016). Between public service and social control: policing dilemmas in the era of immigration enforcement. Social Problems, 63(1), 111-126.

Armenta, A., \& Vega, I.I. (2017). "Latinos and the crimmigration system", race, ethnicity and law (Sociology of crime, law and deviance, Vol. 22), Emerald Publishing Limited, pp. 221-236. https://doi.org/10.1108/S1521613620170000022017

Aron, V., \& Castillo Jara, S. (2020). Reacting to change within change: adaptive leadership and the Peruvian response to Venezuelan immigration. International Migration. https://doi.org/10.1111/imig.12761

Atak, I., \& Simeon, J. C. (Eds.). (2018). The criminalisation of migration: context and consequences. Quebec: Mc Gill-Queen's University Press.

Bahar, D., Dooley, M., \& Selee, A. (2020). Venezuelan migration, crime, and misperceptions: A review of data from Colombia, Peru, and Chile. Migration Policy Institute.

Barker, V. (2012). Global mobility and penal order: criminalizing migration, a view from Europe. Sociology Compass, 6(2), 113-121. https://doi.org/10.1111/j.1751-9020.2011.00444.x.

Berezin, M. (2006). Xenophobia and the new nationalisms. In G. Delanty \& K. Kumar (Eds.), The SAGE handbook of nations and nationalism (pp. 273-284). London: SAGE Publications.

Biehl, K. S. (2015). Governing through Uncertainty: Experiences of Being a Refugee in Turkey as a Country for Temporary Asylum. Social Analysis, 59(1), 57-75.

Boomgaarden, H. G., \& Vliegenthart, R. (2007). Explaining the rise of anti-immigrant parties: the role of news media content. Electoral Studies, 26(2), 404-417.

Bourbeau, P. (2019). Detention and immigration: Practices, crimmigration, and norms. Migration Studies, 7(1), 83-99. 
Bourbeau, P. (2011). The securitization of migration. A study of movement and order. Series Security \& Governance. London: Routledge.

Brubaker, R., Loveman, M., \& Stamatov, P. (2004). Ethnicity as cognition. Theory and Society, 33, 31-64. https://doi.org/10.1023/B:RYSO.0000021405.18890.63.

Burnett, J. (2017). Racial violence and the Brexit state. Race \& Class, 58(4), 85-97. https://doi.org/10.1177/ 0306396816686283.

Burscher, B., van Spanje, J., \& de Vreese, C. H. (2015). Owning the issues of crime and immigration: the relation between immigration and crime news and anti-immigrant voting in 11 countries. Electoral Studies, 38, 5969.

Cantor, D., Freier, L. F., \& Gauci, J.-P. (Eds.). (2015). A Liberal Tide: Immigration and Asylum Law and Policy in Latin America. London: Institute of Latin American Studies, School of Advanced Studies, University of London.

Carroll, H., Luzes, M., Freier, L. F., \& Bird, M. (2020). The migration journey and mental health: evidence from Venezuelan forced migration. SSM - Population Health, 10, 100551-100551. https://doi.org/10.1016/j. ssmph.2020.100551.

Cashdan, E. (2001). Ethnocentrism and xenophobia: a cross-cultural study. Current Anthropology, 42(5), 760765.

Concha, S. (2018). Propuestas para regular las migraciones en Chile y la obstinación del securitismo. URVIO Revista Latinoamericana de Estudios de Seguridad, 23, 110-126.

Condori, M., Reyna, G., Villavicencio, A., Párraga, C., \& Vilcapoma, D. (2020). Éxodo venezolano, inserción laboral y discriminación social en la ciudad de Huancayo, Perú. Revista Espacios, 41(27), 72-83.

Coșkun, E. (2018). Criminalisation and prostitution of migrant women in Turkey: a case study of Ugandan women. Women's Studies International Forum, 68, 85-93.

De Giorgi, A. (2010). Immigration control, post-Fordism, and less elegibility: a materialist critique of the criminalisation of migration across Europe. Punishment and Society., 12(2), 147-167.

Correo, D. (2019). Este es el extranjero que mató a su empleador para robarle. News article. Diario Correo. https://diariocorreo.pe/edicion/cusco/revelan-identidad-de-extranjero-que-mato-su-empleador-en-cuscofotos-874566/. Accessed 16 December 2019.

Dias, G.M. (2014). Migração e Crime: desconstrução das políticas de segurança e tráfico de pessoas. PhD Thesis in Social Anthropology. Campinas, Universidade Estadual de Campinas.

Douglas, K. M., \& Sáenz, R. (2013). The criminalisation of immigrants \& the immigration-industrial complex. Daedalus, 142, 199-227.

Escobar, M. (2016). Captivity beyond prisons: criminalization experiences of Latina (im)migrants. Austin: University of Texas Press.

Estévez, A. (2018a). Guerras necropoliticas y biopolitica de asilo en América del Norte. Ciudad de México: UNAM-UACM.

Estévez, A. (2018b). Biopolítica y necropolítica: ¿constitutivos u opuestos? Espiral. Estudios sobre Estado y Sociedad, 25(73), 9-43.

Fasani, F., Mastrobuoni, G., Owens, E. G., \& Pinotti, P. (2019). Does immigration increase crime? Migration policy and the creation of the criminal immigrant. Cambridge: Cambridge University Press.

Freier, L. F. (2012). "Open doors for (al)most all: visa policies and ethnic selectivity in Ecuador", the Center of Comparative Immigration Studies (CCIS). Working Paper: University of San Diego no. 188.

Freier, L. F., \& Castillo Jara, S. (2020). El Presidencialismo y la Política Migratoria en América Latina: un Análisis de las Reacciones Políticas frente al desplazamiento de Ciudadanos Venezolanos. Internacia, 1, 127.

Freier, L. F., \& Luzes, M. (2021). How humanitarian are humanitarian visas? An analysis of theory and practice in South America. In L. Jubilut, G. Mezzanotti, \& M. Vera Espinoza (Eds.), Latin America and refugee protection: regimes, logics and challenges. Oxford: Berghahn.

Freier, L. F., \& Parent, N. (2019). The Regional Response to the Venezuelan Exodus. Current History, 118(805), 56-61.

Freier, L. F., Bird, M. D., \& Castillo Jara, S. (2021). 'Race,' Ethnicity and Forced Displacement. In P. Adey, K. Brickell, J. Bowstead, V. Desai, M. Dolton, A. Pinkerton, \& A. Siddiqi (Eds.), The Handbook of Displacement. London: Palgrave Macmillan.

Freier, L. F., \& Vera Espinoza, M. (2021). COVID-19 \& Immigrants' Increased Exclusion: The Politics of Immigrant Integration in Chile and Peru. Frontiers in Human Dynamics. Forthcoming.

Garcia, G. (2020). Venezolanos en Ecuador: prácticas de seguridad, criminalización y control. https://www.law. ox.ac.uk/research-subject-groups/centre-criminology/centreborder-criminologies/blog/2020/03/venezolanosen-0. Accessed 24 August 2020. 
Gestión (2019). ¿Dónde se ubican los ciudadanos venezolanos en el Perú por domicilio y trabajo? https://gestion. pe/economia/empresas/ubican-ciudadanos-venezolanos-peru-domicilio-270124-noticia/. Accessed 17 July 2020.

Hammerstad, A. (2014). The rise and decline of a global security actor: UNHCR, refugee protection and security. Oxford: Oxford University Press.

Hjerm, M. (1998). National identities, national pride and xenophobia: a comparison of four Western countries. Acta Sociologica, 41(4), 335-347. https://doi.org/10.1177/000169939804100403.

Huysmans, J. (2006). The politics of insecurity: fear, migration and asylum in the EU. Abingdon: Routledge.

Hodge, P. (2015). A grievable life? The criminalisation and securing of asylum seeker bodies in the "violent frames' of Australia's Operation Sovereign Borders. Geoforum, 58, 122-131. https://doi.org/10.1016/j. geoforum.2014.11.006.

IDEHPUCP \& IOP (2020). Cambios en las Actitudes hacia los Inmigrantes Venezolanos en Lima-Callao 20182019 http://repositorio.pucp.edu.pe/index/bitstream/handle/123456789/169459/IOP_1119_01_R2.pdf? sequence=1\&isAllowed=y. Accessed 3 July 2020.

INEI (2018a). Producción y empleo informal en el Perú. Cuenta satélite de la economía informal 2007-2017. https://www.inei.gob.pe/media/MenuRecursivo/publicaciones_digitales/Est/Lib1589/libro.pdf. Accessed 6 July 2020.

INEI (2018b). Percepción de Inseguridad. https://www.inei.gob.pe/media/MenuRecursivo/publicaciones digitales/Est/Lib1519/cap04.pdf. Accessed 24 August 2020.

INEI (2019). Condiciones de Vida de la Población Venezolana que reside en Perú. Resultados de la "Encuesta dirigida a la población venezolana que reside en el país” ENPOVE 2018. https://www.inei.gob.pe/media/ MenuRecursivo/publicaciones_digitales/Est/Lib1666/.

IOM (2020). Venezuelan refugee and migrant crisis. https://www.iom.int/venezuela-refugee-and-migrant-crisis. Accessed 19 June 2020.

Kienast, J. (2020). Forced migrants as a security threat: challenging criminalization trends in Austria under presumed links of asylum and terrorism. In J. C. Simeon (Ed.), Terrorism and Asylum, International Refugee Law Series (Vol. 17, pp. 342-372). Netherlands: Brill.

Kil, S. H., \& Menjivar, C. (2006). The "war on the border": criminalizing immigrants and militarizing the USMexico border. In R. Martinez \& A. Valenzuela (Eds.), Immigration and crime: race, ethnicity, and violence (pp. 164-188). New York: New York University Press.

Koopmans, R. (1996). Explaining the rise of racist and extreme right violence in Western Europe: grievances or opportunities? European Journal of Political Research, 30(2), 185-216.

Landau, L. (Ed.). (2012). Exorcising the demons within: xenophobia, violence and statecraft in contemporary South Africa. Tokyo, New York, \& Paris: United Nations University Press.

Lentin, A. (2011). Racism and Ethnic Discrimination. New York: Rosen Publishing.

Leon Rojas, A. (2020). Migratory governability, reinforcing the securitization model in South America? The Venezuelan exodus and its challenges for the Colombian state. Estudios Politicos, 57, 210-228. https://doi. org/10.17533/udea.espo.n57a10.

Lowenkron, L., \& Piscitelli, A. (2019). Trabalhadoras/es migrantes e o tráfico internacional de pessoas em dois lados do oceano. In A. F. Navia, S. C. Hamid, B. M. Munem, \& C. P. Gomes Pessoas (Eds.), Em movimento: Prática de gestão, categorias de direito e agencias (pp. 135-171). Rio de Janeiro: Fundação Casa de Rui Barbosa.

Maneri, M. (2011). Media discourse on immigration: control practices and the language we live. In S. Palidda (Ed.), Racial criminalisation of migrants in the $21^{\text {st }}$ century (pp. 77-94). Farnham: Ashgate.

Martinez, D., \& Slack, J. (2013). What part of "illegal” don't you understand? The social consequences of criminalizing unauthorized Mexican migrants in the United States. Social \& Legal Studies, 22(4), 535-551.

Melossi, D. (2003). In a peaceful life: migration and crime of modernity in Europe/Italy. Punishment and Society., 5(4), 371-397.

Menjívar, C. (2016). Immigrant criminalization in law and the media: effects on Latino immigrant workers' identities in Arizona. American Behavioral Scientist, 60(5-6), 597-616. https://doi.org/10.1177/ 0002764216632836 .

Menjívar, C., \& Abrego, L. J. (2012). Legal violence: immigration law and the lives of central American immigrants. American Journal of Sociology, 117(5), 1380-1421. https://doi.org/10.1086/663575.

Menjívar, C., \& Kanstroom, D. (Eds.). (2014). Constructing immigrant “illegality”: critiques, experiences, and responses. New York: Cambridge University Press.

MINJUSDH, Ministerio Nacional de Justicia y Derechos Humanos, (2019). Informe sobre la discriminación en medios de comunicación en el Perú, con especial énfasis en la discriminación étnico-racial. https://cdn. www.gob.pe/uploads/document/file/297520/Informe_CONACOD_Discriminaci\%C3\%B3n_Medios.pdf. Accessed 16 December 2019. 
Nunziata, L. (2015). Immigration and crime: evidence from victimization data. Journal of Population Economics, 28(3), 697-736.

Oliveira Moreira, T. (2020). El regreso de la crimigración y el desvanecimiento del carácter humanista de la Ley de Migración Brasileña. Latin American Law Review, 5, 97-120.

Orr, Z., \& Ajzenstadt, M. (2020). Beyond control: the criminalization of African asylum seekers in Israel. International Review of Sociology, 30(1), 142-165.

Palma, M. (2020). La criminalización del retorno en Venezuela. Proyecto Migración Venezuela. https:// migravenezuela.com/web/articulo/la-criminalizacion-del-retorno-en-venezuela/2006. Accessed 30 June 2020.

Parkin, J. (2013). The criminalisation of migration in Europe. A State-of-the-Art of the Academic Literature and Research. CEPS Paper in Liberty and Security in Europe. CEPS. https://www.ceps.eu/system/files/ Criminalisation\%20 of\%20Migration\%20in\%20Europe \%20J\%20Parkin\%20FIDUCIA\%20final.pdf. Accessed 11 December 2019.

Parmar, A. (2019). Arresting (non)citizenship: the policing migration nexus of nationality, race and criminalization. Theoretical Criminology, 24(1), 28-49.

Pecho Gonzáles, A. (2020). Migración venezolana: de la política "solidaria" al peligroso camino de la criminalización. Ideele Revista, $290 \mathrm{https} / /$ revistaideele.com/ideele/content/migraci\%C3\%B3nvenezolana-de-la-pol\%C3\%ADtica-\%E2\%80\%9Csolidaria\%E2\%80\%9D-al-peligroso-camino-de-lacriminalizaci\% $3 \% \mathrm{~B} 3 \mathrm{n}$.

Pérez, L. M., \& Ugarte, D. (forthcoming). Venezuelan women in Peru: at the borders of nationality, gender, and survival migration. Journal of International Migration and Integration.

Pineda, E., \& Ávila, K. (2019). Aproximaciones a la Migración Colombo-Venezolana: Desigualdad, Prejuicio y Vulnerabilidad. Clivatge, 7, 46-97. https://doi.org/10.1344/CLIVATGE2019.7.3.

Provine, D. M., \& Doty, R. L. (2011). The criminalization of immigrants as a racial project. Journal of Contemporary Criminal Justice, 27, 261-277.

Ratha, D., \& Shaw, W. (2007). South-South migration and remittances. Washington, DC: Development Prospects Group, World Bank.

Reid, H. E., Adleman, R. M., \& Jaret, C. (2005). The immigration-crime relationship: evidence across US metropolitan areas. Social Science Research, 34(4), 757-780.

Romero, L. A., \& Zarrugh, A. (2018). Islamophobia and the making of Latinos/as into terrorist threats. Ethnic and Racial Studies, 41(12), 2235-2254. https://doi.org/10.1080/01419870.2017.1349919.

Ruiz, M. C., \& Álvarez Velasco, S. (2019). Excluir para proteger: la "guerra" contra la trata y el tráfico de migrantes y las nuevas lógicas de control migratorio en Ecuador. Revista Estudios Sociológicos, 37(111), $689-726$.

Sáenz, R., \& Douglas, K. M. (2015). A call for the racialization of immigration studies: on the transition of ethnic immigrants to racialized immigrants. Sociology of Race and Ethnicity, 1(1), 166-180. https://doi.org/10. $1177 / 2332649214559287$.

Sánchez, G. (2015). Human smuggling and border crossings. London: Routledge.

Seele, A., Bolter, J., Muñoz-Pogossian, B, \& Hazán, M. (2019). Creativity amid crisis: legal pathways for Venezuelan migrants and refugees in Latin America. Policy Brief. Migration Policy Institute. https://www. migrationpolicy.org/sites/default/files/publications/VenezuelansLegalPathwaysBrief-English-Final.pdf. Accessed 11 December 2019.

Sigona, N., \& Trehan, N. (2011). The (re)criminalisation of Roma communities in a neoliberal Europe. In S. Palidda (Ed.), Racial criminalisation of migrants in the 21st century (pp. 119-132). Farnham: Ashgate.

Sivanandan, A. (2007). Racism, liberty and the war on terror. Race \& Class, 48(4), 45-96.

Sputnik (2019). Municipio en Perú no logra aprobar ordenanza que buscaba expulsar a migrantes venezolanos. https://mundo.sputniknews.com/america-latina/201910241089083061-municipio-en-peru-no-logra-aprobarordenanza-que-buscaba-expulsar-a-migrantes-venezolanos/ . Accessed 17 July 2020.

Tafira, K. (2015). Is xenophobia racism? Anthropology Southern Africa, 34(3-4), 114-121. https://doi.org/10. $1080 / 23323256.2011 .11500015$.

Tufail, W., \& Poynting, N. (2013). A common 'outlawness': criminalisation of Muslim minorities in the UK and Australia. International Journal for Crime, Justice, and Social Democracy, 2(3), 43-54.

Tumlin, K. C. (2004). Suspect first: how terrorism policy is reshaping immigration policy. California Law Review, 92, 1173-1239.

United Nations Department of Economic and Social Affairs (UN DESA) (2012). Migrants by origin and destination: the role of South-South migration. Population Facts. UN DESA Population Division. https:// www.un.org/en/development/desa/population/publications/pdf/popfacts/popfacts_2012-3_South-South_ migration.pdf. Accessed 11 December 2019.

UNHCR (2019a). Monitoreo de Protección. Marzo 2019. Report. https://www.refworld.org.es/docid/5cc8e6244. html. Accessed 11 December 2019. 
UNHCR (2019b). Monitoreo de Protección. May/June 2019. Report. https://r4v.info/es/documents/download/ 70520. Accessed 11 December 2019.

UNHCR \& OIM (2020). Plataforma de Coordinación para Refugiados y Migrantes de Venezuela. https://r4v. info/es/situations/platform\#. Accessed 16 December 2019.

van Klingeren, M., Boomgaarden, H. G., Vliegenthart, R., \& de Vreese, C. H. (2015). Real world is not enough: the media as an additional source of negative attitudes toward immigration, comparing Denmark and the Netherlands. European Sociological Review, 31(3), 268-283.

Varela, A. (2020). Apuntes para un feminismo antirracista después de las caravanas de migrantes. In V. Gago (Ed.), La Internacional Feminista Luchas en los territorios y contra el neoliberalismo. Buenos Aires: Tinta Limón.

Wagner, U.B. (2010). The American dream's sojourn in Latin America: the dynamics of irregular migration flows through Colombia and Ecuador. Master of Science Dissertation, Oxford University.

Weber, L., \& Bowling, B. (2008). Valiant beggars and global vagabonds: select, eject, immobilize. Theoretical Criminology., 12, 355-375.

World Bank (2019). Una Oportunidad para todos: Los migrantes y refugiados venezolanos y el desarrollo del Perú. Report. http://documents.worldbank.org/curated/en/107621574372585665/pdf/Una-Oportunidadpara-Todos-Los-Migrantes-y-Refugiados-Venezolanos-y-el-Desarrollo-del-Per\%C3\%BA.pdf. Accessed 16 December 2019.

Wortley, S. (2009). Introduction. The immigration-crime connection: competing theoretical perspectives. Journal of International Migration and Integration, 10(4), 349-358.

Publisher's Note Springer Nature remains neutral with regard to jurisdictional claims in published maps and institutional affiliations. 